\title{
Pemetaan Kualitas Permukiman dengan Menggunakan Sistem Informasi Geografis di Kelurahan Sukun, Kecamatan Sukun, Kota Malang
}

\author{
Yoseph Nong Maryono ${ }^{1, *}$, Achmad Maulana Malik Jamil ${ }^{1}$, Dwi Kurniawati ${ }^{1}$ \\ ${ }^{1}$ Program Studi Pendidikan Geografi, Universitas Kanjuruhan Malang, Malang 65148, Indonesia \\ Email : yosephnongmaryono@gmail.com,maulana3188@gmail.com,dwikur@unikama.ac.id
}

Dikirim : 31 Juli 2019

Diterima: 1 Septenber 2019

\begin{abstract}
Abstrak: Permukiman adalah bagian dari kehidupan manusia yang merupakan lingkungan hidup atau tempat tinggal dari manusia itu sendiri. Kondisi suatu permukiman sangat berkaitan erat dengan kehidupan manusia didalamnya dan saling mempengaruhi. Kondisi permukiman yang kurang baik akan mengganggu kesejahteraan kehidupan manusia, begitu pula kegiatan dari manusia akan mempengaruhi kondisi permukimannya. Penelitian ini bertujuan untuk mengetahui kualitas permukiman di wilayah Kelurahan Sukun, Kecamatan Sukun, Kota Malang. Jenis penelitian yang digunakan yaitu penelitian yang berbentuk survey. Untuk mengetahui kualitas permukiman di Kelurahan Sukun, Kecamatan Sukun Kota Malang dibutuhkan parameter penentu (indikator penentu) yang diinterpretasikan dari citra resolusi tinggi (Google Earth). Setelah dilakukan pengumpulan data, pengukuran di lapangan dan interpretasi citra serta diolah dan dianalisis, didapatkan hasil bahwa Kelurahan Sukun termasuk dalam kualitas permukiman sedang karena jumlah semua parameter penentu kualitas permukiman hanya mencapai tingkat sedang. Disimpulkan bahwa kualitas permukiman di Kelurahan Sukun termasuk kedalam Kualitas sedang. Kualitas permukiman di Kelurahan Sukun yang masuk klasifikasi sedang dipengaruhi oleh pembangunan yang sembarangan yang mengakibatkan beberapa indikator penentu kualitas permukiman menjadi buruk. Oleh karena itu diharapkan kepada pemerintah dan masyarakat untuk lebih memperhatikan lagi pembangunan dalam permukiman agar kualitas permukiman tersebut tetap baik.
\end{abstract}

Kata kunci: pemetaan, kualitas permukiman, sistem informasi geografis

Abstract: Settlements are a part of human life which is the environment or place of residence of humans themselves. The condition of a settlement is closely related to human life in it and affects each other. Poor settlement conditions will disrupt the welfare of human life, as well as activities from humans will affect the condition of their settlements. This study aims to determine the quality of settlements in the Sukun Urban Village, Sukun District, Malang City. The type of research used is research in the form of a survey. To find out the quality of settlements in Sukun Subdistrict, Malang City Breadfruit District, determinant parameters (determinant indicators) are interpreted from high-resolution images (Google Earth). After collecting data, measuring in the field and interpreting the image and processing and analyzing, the results showed that the Sukun Village was included in the quality of moderate settlements because the number of all determinants of settlement quality only reached a moderate level. It was concluded that the quality of settlements in Sukun Urban Village was of moderate quality. The quality of settlements in the Sukun Urban Village which are classified as being affected by careless development has resulted in several poor indicators of settlement quality. Therefore, it is hoped that the government and the community will pay more attention to development in settlements so that the quality of these settlements remains good.

Keywords: mapping, quality of settlements, geographic information systems 


\section{Pendahuluan}

Pertumbuhan penduduk yang cepat menyebabkan semakin besarnya kebutuhan ruang untuk tempat tinggal sehingga menyebabkan berkembangnya permukiman tidak terkontrol, terutama hunian liar atau permukiman kumuh yang dapat mengakibatkan menurunnya kualitas permukiman, khususnya di daerah perkotaan. Kota merupakan pusat dari permukiman yang relatif besar dan menjadi pusat kegiatan manusia dan menawarkan kesempatan untuk mendapatkan hidup lebih baik dari pada di daerah pedesaan (Prasetyo et.al, 2013). Berkembangnya suatu kota pasti akan diikuti oleh pertambahan jumlah penduduk. Salah satu permasalahan yang muncul seiring dengan perkembangan suatu kota adalah masalah perumahan dan pemukiman, menurut (Bintarto dalam Koestoer, 2001:46).

Permukiman yang akan dibahas adalah permukiman yang berada di wilayah kota Malang lebih khususnya lagi di Kelurahan Sukun, Kecamatan Sukun, Kota Malang. Pada tahun 2015, disebutkan luas kawasan kumuh di Kota Malang sesuai dengan Surat Keputusan Walikota Malang Nomor 188.45/86/35.73.112/2015 tahun 2015 mencapai 608,6 Ha. Wilayah dengan kawasan kumuh terluas berada di Bareng (81,56 Ha); disusul Ciptomulyo (62,6 Ha); Penanggungan $(53,01 \mathrm{Ha})$; dan Kasin $(48,20 \mathrm{Ha})$. Sementara jika dirinci per kecamatan, kawasan kumuh terbanyak terdapat di Kecamatan Klojen (346,51 Ha); Sukun (132,8 Ha); Kedungkandang (72,9 Ha); Lowokwaru (31,35 Ha); dan Blimbing (25,04 Ha), (Akbar dan Alfian, 2018).

Keterkaitan antara permukiman kumuh dan kualitas permukiman sangatlah erat. Hal ini dikarenakan jika suatu lingkungan termasuk dalam lingkungan kumuh berarti permukiman tersebut tidak tertata dengan baik dari bangunannya beserta sarana dan prasarana yang kurang memadai. Hal ini tercantum dalam (UU No.1 tahun 2011) Pemukiman kumuh adalah permukiman yang tidak layak huni karena ketidakteraturan bangunan, tingkat kepadatan bangunan yang tinggi, dan kualitas bangunan serta sarana dan prasarana yang tidak memenuhi syarat. Perumahan kumuh adalah perumahan yang mengalami penurunan kualitas fungsi sebagai tempat hunian.

Ditinjau dari data kawasan kumuh dan permasalahan di atas, maka direncanakan pembuatan suatu peta atau dengan kata lain pemetaan permukiman dimana akan dikaji kualitas dari permukiman tersebut dalam suatu wilayah. Dengan adanya pemetaan ini diharapkan bahwa, penduduk yang bertambah secara pesat sekalipun tidak akan membuat kualitas permukiman menjadi buruk dengan adanya pembangunan tempat tinggal yang sembarangan, sehingga kehidupan dan kesejahteraan penduduk bisa terjamin dengan baik.

Dilakukan penelitian dan pemetaan kualitas permukiman di Kelurahan Sukun bertujuan untuk mengetahui kualitas permukiman yang ada di Kelurahan Sukun itu Sendiri. Dengan adanya hasil dari tujuan peneliti diharapkan dapat membantu penataan, penjagaan, dan peningkatan kualitas permukiman agar dapat membuat masyarakat menjadi nyaman dan sejahtera.

\section{Metode Penelitian}

Penelitian ini menggunakan penelitian survey. Peneliti menggunakan penelitian survey karena data yang harus diolah bukan hanya data sekunder (seperti data monografi dan peta pembagian tiap RW) yang didapat dari pemerintahan, melainkan data primer seperti lebar jalan dan keberadaan pohon pelindung yang harus dilihat dan diukur langsung dilapangan. 


\section{Pengumpulan data}

Prosedur pengumpulan datanya berawal dari pengambilan citra satelit resolusi tinggi di Google Earth, dan dilanjutkan dengan observasi langsung dilapangan dengan tujuan agar dapat mempermudah penyesuaian atau analisis citra satelit serta dilanjutkan dengan pengumpulan data dari pemerintah tentang jumlah penduduk dan persebarannya agar nanti dapat menyesuaikan dengan data awal.

Dalam penelitian ini pengambilan sampel menggunakan Purposive Sampling. Purposive Sampling adalah teknik penetuan sampel dengan pertimbangan tertentu (Sugiyono, 2012:68). Sampel dari penelitian ini adalah Kelurahan Sukun, Kecamatan Sukun, Kota Malang.

Kelurahan Sukun dijadikan karena Kelurahan Sukun merupakan salah satu kelurahan yang terdapat di Kecamatan Sukun dan Kecamatan Sukun merupakan salah satu kecamatan dengan luas kawasan kumuh sekitar (132,8 Ha). Kelurahan Sukun juga yang mempunyai jarak yang relatif dekat dengan pusat Kota Malang serta mempunyai jarak yang cukup dekat pula dengan kantor Kecamatan Sukun.

Pengambilan sampel lain juga dilakukan khusus di RW 05, RW 07, dan RW 08 untuk mengetahui indikator penentu kualitas permukiman yaitu, ketersediaan air bersih, polusi udara, dan polusi suara. Diambil ketiga RW diatas dikarenakan di Kelurahan Sukun dilihat dari citra maupun di lapangan, RW 05, RW 07, dan RW 08 merupakan RW yang tertata rapi untuk bangunannya serta salah satu dari RW tersebut adalah kawasan perumahan yakni, RW 07.

\section{Analisis data}

Metode analisis data yang digunakan dalam penelitian ini adalah metode interpretasi visual dan overlay. 'Interpretasi citra merupakan kegiatan mengkaji foto udara atau citra yang bertujuan untuk menganalisis objek dan menentukan arti pentingya objek tersebut (Ambarasakti, 2013).' Overlay yaitu kemampuan untuk menempatkan grafis satu peta diatas grafis peta yang lain dan menampilkan hasilnya di layar komputer atau pada plot. Secara singkatnya, overlay menampalkan suatu peta digital pada peta digital yang lain beserta atributatributnya dan menghasilkan peta gabungan keduanya yang memiliki informasi atribut dari kedua peta tersebut.

Dalam penelitian, interpretasi berfungsi untuk menentukan letak dan lokasi dari pada permukiman, jalan, jalur sungai, dan lain-lain sebelum melakukan pengukuran dilapangan. Sedang overlay adalah salah satu cara menggabungkan grafis peta atau menggabungkan beberapa peta dengan menggunakan atau memilih tema dalam aplikasi Arcgis 10.2 .

Sebelum melakukan pemetaan, hasil dari pengukuran dan pengamatan dilapangan akan dihitung atau diberi skor dari masing-masing parameter penentu kualitas permukiman yang bersumber dari (Ditjen Cipta Karya, Dep. PU (2006) dalam Mudzakir), yaitu Klasifikasi Kepadatan Permukiman, Klasifikasi Tata Letak Bangunan, Klasifikasi Lebar Jalan Masuk, Klasifikasi Lokasi Permukiman, Klasifikasi Kondisi Jalan Masuk, Klasifikasi Pohon Pelindung, Klasifikasi Ketersdiaan Air Bersih, Klasifikasi Polusi Udara, Klasifikasi Polusi Suara. Dan parameter-parameter penentu tersebut ditunjukan dalam tabel-tabel sebagai berikut: 
Tabel 1. Klasifikasi Kepadatan Permukiman

\begin{tabular}{llll}
\hline \multicolumn{1}{c}{ Kriteria } & Kriteria & Harkat (Score) \\
\hline $\begin{array}{l}\text { Kepadatan rumah rata-rata } \\
\text { pada permukiman jarang (< } \\
40 \%)\end{array}$ & Baik & 3 & \\
\hline $\begin{array}{l}\text { Kepadatan rumah rata-rata } \\
\text { pada permukiman sedang }(40 \%\end{array}$ & Sedang & 2 \\
$-60 \%)$ & & 1 \\
\hline $\begin{array}{l}\text { Kepadatan rumah rata-rata } \\
\text { pada permukiman Padat (> }\end{array}$ & Buruk & \\
$60 \%)$ & & \\
\hline (Sumber : Ditjen Cipta Karya, Dep. PU (2006) dalam Mudzakir) &
\end{tabular}

Sebelum dapat menentukan kriteria kepadatan suatu permukiman harus dilakukan suatu perhitungan dengan menggunakan rumus sebagai berikut:

Rumus Kepadatan Permukiman:

Kepadatan Permukiman $=\frac{\Sigma \text { Seluruh Luas Atap }}{\Sigma \text { Luas Blok Permukiman dalam Unit Permukiman }} \times 100 \% \ldots$ (1)

(Sumber : Ditjen Cipta Karya, Dep. PU (2006) dalam Mudzakir)

Tabel 2. Klasifikasi Tata Letak Bangunan

\begin{tabular}{|c|c|c|}
\hline Kriteria & Klasifikasi & Harkat(Score) \\
\hline $\begin{array}{l}\text { Jika lebih dari atau sama } \\
\text { dengan } 50 \% \text { bangunan- } \\
\text { bangunan sedang tertata teratur }\end{array}$ & Baik & 3 \\
\hline $\begin{array}{l}\text { Jika } 25 \%-50 \% \text { bangunan } \\
\text { tertata teratur }\end{array}$ & Sedang & 2 \\
\hline $\begin{array}{l}\text { Jika }<25 \% \text { bangunan tertata } \\
\text { teratur }\end{array}$ & Buruk & 1 \\
\hline
\end{tabular}

Sebelum dapat menentukan kriteria tata letak suatu permukiman harus dilakukan suatu perhitungan dengan menggunakan rumus sebagai berikut:

Rumus Tata Letak Bangunan:

Tata letak bangunan $=\frac{\Sigma \text { Bangunan yang Tertata Teratur }}{\Sigma \text { Luas Blok Permukiman Dalam Unit Permukiman }} \times 100 \%$

(Sumber : Ditjen Cipta Karya, Dep. PU (2006) dalam Mudzakir)

Tabel 3. Klasifikasi Lebar Jalan Masuk

\begin{tabular}{lcc}
\hline \multicolumn{1}{c}{ Kriteria } & Klasifikasi & Harkat(Score) \\
\hline $\begin{array}{l}\text { Jika lebar jalan }>6 \mathrm{~m} \text { dapat } \\
\text { dilalui 2-3 mobil }\end{array}$ & Baik & 3 \\
\hline $\begin{array}{l}\text { Jika lebar jalan } 4-6 \mathrm{~m} \text { dapat } \\
\text { dilalui 1-2 mobil }\end{array}$ & Sedang & 2 \\
\hline Jika lebar jalan < 4m & Buruk & 1 \\
\hline (Sumber : Ditjen Cipta Karya, Dep. $P U(2006)$ dalam Mudzakir)
\end{tabular}


Tabel 4. Klasifikasi Lokasi Permukiman

\begin{tabular}{lcc}
\hline \multicolumn{1}{c}{ Kriteria } & Klasifikasi & Harkat (Score) \\
\hline $\begin{array}{l}\text { Bila lokasi permukiman jauh } \\
\text { dari polusi (terminal, stasiun, } \\
\text { pabrik) atau bencana (sungai, } \\
\text { gunung) dan masih dekat }\end{array}$ & Baik \\
dengan kota. & & \\
\hline $\begin{array}{l}\text { Bila lokasi permukiman tidak } \\
\text { terpengaruh secara langsung } \\
\text { dengan kegiatan sumber polusi } \\
\text { (terminal, stasiun, pabrik) atau } \\
\text { bencana (sungai, gunung). }\end{array}$ & Sedang & 2 \\
\hline $\begin{array}{l}\text { Bila lokasi permukiman dekat } \\
\text { dengan sumber polusi udara } \\
\text { maupun suara (terminal, }\end{array}$ & & \\
stasiun, pabrik) atau bencana \\
alam (sungai, gunung)
\end{tabular}

Tabel 5. Klasifikasi Kondisi Jalan Masuk

\begin{tabular}{lcc}
\hline \multicolumn{1}{c}{ Kriteria } & Klasifikasi & Harkat(Score) \\
\hline $\begin{array}{l}\text { Jika }>50 \% \text { jalan pada } \\
\text { blok permukiman tersebut telah } \\
\text { diaspal atau semen }\end{array}$ & Baik & 3 \\
\hline $\begin{array}{l}\text { Jika 25\% }-50 \% \text { jalan pada blok } \\
\text { permukiman tersebut belum } \\
\text { diaspal atau semen }\end{array}$ & Sedang & 2 \\
\hline $\begin{array}{l}\text { Jika }<25 \% \text { jalan pada blok } \\
\text { permukiman tersebut telah } \\
\text { diaspal / disemen }\end{array}$ & Buruk & 1 \\
\hline Sumber : Ditjen Cipta Karya, Dep. PU (2006) dalam Mudzakir)
\end{tabular}

Tabel 6. Klasifikasi Pohon Pelindung

\begin{tabular}{|c|c|c|}
\hline Kriteria & Klasifikasi & Harkat(Score) \\
\hline Jika memiliki pohon pelindung & Baik & 2 \\
\hline $\begin{array}{l}\text { Jika tidak memiliki pohon } \\
\text { pelidung }\end{array}$ & Buruk & 1 \\
\hline
\end{tabular}

Tabel 7 Klasifikasi Ketersdiaan Air Bersih

\begin{tabular}{lcc}
\hline \multicolumn{1}{c}{ Kriteria } & Klasifikasi & Harkat(Score) \\
\hline$>50 \%$ dalam permukiman & Baik & 3 \\
menggunakan PDAM/PAM & & 2 \\
\hline$>25 \%-50 \%$ dalam & Sedang & \\
permukiman menggunakan & & 1 \\
PDAM/PAM & Buruk & \\
\hline$<25 \%$ dalam permukiman & & \\
menggunakan PDAM/PAM & (Sumber : Ditjen Cipta Karya, Dep. PU (2006) dalam Mudzakir)
\end{tabular}

(Sumber : Ditjen Cipta Karya, Dep. PU (2006) dalam Mudzakir)

Tabel 8 Klasifikasi Polusi Udara

\begin{tabular}{lcc}
\hline \multicolumn{1}{c}{ Kriteria } & Klasifikasi & Harkat(Score) \\
\hline Tidak mengganggu & Baik & 3 \\
\hline Sedikit mengganggu & Sedang & 2 \\
\hline Sangat mengganggu & Buruk & 1 \\
\hline (Sumber $:$ Ditjen Cipta Karya Dep $P U(2006)$ dalam Mudzakir)
\end{tabular}

(Sumber : Ditjen Cipta Karya, Dep. PU (2006) dalam Mudzakir) 
Tabel 9 Klasifikasi Polusi Suara

\begin{tabular}{lcc}
\multicolumn{1}{c}{ Kriteria } & Klasifikasi & Harkat(Score) \\
\hline Tidak mengganggu & Baik & 3 \\
\hline Sedikit mengganggu & Sedang & 2 \\
\hline Sangat mengganggu & Buruk & 1 \\
\hline
\end{tabular}

(Sumber : Ditjen Cipta Karya, Dep. PU (2006) dalam Mudzakir)

Setelah semuanya sudah diketahui selanjutnya adalah melakukan klasifikasi untuk setiap parameter. Klasifikasi ini bertujuan untuk mengkelaskan blok permukiman kedalam kelas baik, sedang, atau buruk. Pertama-tama menemukan nilai tertinggi dan terendah, kita harus terlebih dahulu menghitung jumlah harkat (skor) atau mencari harkat total (skor total dengan rumus sebagai berikut:

Harkat Total Citra $=(\mathrm{Ax} 3)+(\mathrm{Bx} 1)+(\mathrm{Cx} 2)+(\mathrm{Dx} 3)+(\mathrm{Ex} 2)+(\mathrm{Fx} 2)+(\mathrm{G})+(\mathrm{H})+(\mathrm{I})$

(Sumber : Ditjen Cipta Karya, Dep. PU (2006) dalam Mudzakir)

Keterangan:

A : Harkat kepadatan permukiman

B : Harkat tata letak permukiman

C : Harkat pohon pelindung jalan

D : Harkat lebar jalan masuk

E : Harkat kondisi jalan masuk

F : Harkat lokasi permukiman

G : Harkat ketersediaan air bersih

$\mathrm{H} \quad$ : Harkat polusi udara

I : Harkat polusi suara

Setelah menemukan nilai tertinggi dan nilai terendah, Selanjutnya menghitung interval kelas (range). Rumus yang digunakan adalah :

Interval Kelas $=\frac{(\text { Skor tertinggi-skor terendah })}{\text { jumlah kelas yang diinginkan }}$

(Sumber : Ditjen Cipta Karya, Dep. PU (2006) dalam Mudzakir)

\section{Hasil Penelitian}

Setelah melakukan penelitian atau pengumpulan data dan pengamatan, peneliti telah mendapatkan data yang akan diolah dan di tunjukan dalam gambar berupa peta dengan data awal setelah interpretasi adalah bahwa luas dari kelurahan sukun \pm 123 hektar. Data yang selanjutnya akan diolah atau dianalisis adalah data klasifikasi yang akan menunjukan kondisi atau kualitas Kelurahan Sukun termasuk kedalam kondisi atau kualitas yang baik, sedang, atau buruk berdasarkan kepadatan permukiman, tata letak bangunan, lebar jalan masuk, lokasi permukiman, kondisi jalan masuk, pohon pelindung, ketersediaan air, polusi udara dan polusi suara.

1. Kepadatan permukiman

Kepadatan permukiman adalah padat atau jarangnya permukiman dalam suatu wilayah. Permukiman yang padat atau jarang atau jarang dapat dibedakan dengan menghitung luas 
semua atap rumah dibagi dengan luas wilayah atau blok permukiman atau luas atap rumah tadi dan dikalikan dengan $100 \%$.

Tabel 11. Luas RW Dan Luas Permukiman (Atap Rumah)

\begin{tabular}{ccccc}
\hline No. & RW & $\begin{array}{c}\text { Luas RW/blok } \\
\text { permukiman (ha) }\end{array}$ & $\begin{array}{c}\text { Luas Atap Rumah/Luas } \\
\text { Permukiman (ha) }\end{array}$ & $\begin{array}{c}\text { Hasil kepadatan } \\
\text { Permukiman }(\%)\end{array}$ \\
\hline 1. & 01 & 16,76 ha & 9,16 ha & $54,65 \%$ \\
\hline 2. & 02 & 17,93 ha & 10,14 ha & $56,55 \%$ \\
\hline 3. & 03 & 14,94 ha & 3,99 ha & $26,71 \%$ \\
\hline 4. & 04 & 37,00 ha & 20,12 ha & $54,38 \%$ \\
\hline 5. & 05 & 5,15 ha & 3,77 ha & $73,20 \%$ \\
\hline 6. & 06 & 12,12 ha & 9,03 ha & $74,50 \%$ \\
\hline 7. & 07 & 11,64 ha & 7,36 ha & $63,23 \%$ \\
\hline 8. & 08 & 6,75 ha & 5,21 ha & $77,18 \%$
\end{tabular}

Sumber: hasil analisis peneliti, 2019

Tabel 12. Klasifikasi Kepadatan Permukiman Di Kelurahan Sukun

\begin{tabular}{cccc}
\hline No. & RW & Klasifikasi & Harkat (skor) \\
\hline 1. & 01 & Sedang & 2 \\
\hline 2. & 02 & Sedang & 2 \\
\hline 3. & 03 & Baik & 3 \\
\hline 4. & 04 & Sedang & 2 \\
\hline 5. & 05 & Buruk & 1 \\
\hline 6. & 06 & Buruk & 1 \\
\hline 7. & 07 & Buruk & 1 \\
\hline 8. & 08 & Buruk & 1 \\
\hline
\end{tabular}

Sumber: hasil analisis peneliti, 2019

2. Tata letak bangunan

Tata letak bangunan yang akan dimasukan dalam klasifikasi adalah tata letak bangunan yang baik dimana besar bangunan permukiman rata-rata hampir sama dan tertata rapih. Setelah diamati melalui Google Earth dan pengamatan langsung peneliti telah menetukan lokasi-lokasi yang termasuk permukiman tertata baik dan sedang yang kemudian dicari luasannya dan dibagi luas blok permukiman dan dikalikan dengan 100\% agar dapat menamukan hasil yang kemudian dimasukan dalam beberapa klasifikasi seperti tabel berikut:

Tabel 13. Klasifikasi Tata Letak Permukiman di Kelurahan Sukun

\begin{tabular}{cccccc}
\hline No. & RW & $\begin{array}{c}\text { Luas RW/Blok } \\
\text { Permukiman (ha) }\end{array}$ & $\begin{array}{c}\text { Luas Bangunan } \\
\text { Tertata Baik dan } \\
\text { tertata Sedang (ha) }\end{array}$ & Hasil (\%) & Klasifikasi (skor) \\
\hline 1. & 01 & 16,76 ha & 2,63 ha & $15,69 \%$ & Buruk (1) \\
\hline 2. & 02 & 17,93 ha & 4,59 ha & $25,60 \%$ & Sedang (2) \\
\hline 3. & 03 & 14,94 ha & 1,41 ha & $9,43 \%$ & Buruk (1) \\
\hline 4. & 04 & 37,00 ha & 10,03 ha & $27,11 \%$ & Baik (3) \\
\hline 5. & 05 & 5,15 ha & 3,56 ha & $69,13 \%$ & Baik (3) \\
\hline 6. & 06 & 12,12 ha & 6,12 ha & $50,49 \%$ & Baik (3) \\
\hline 7. & 07 & 11,64 ha & 7,36 ha & $63,23 \%$ & Baik (3) \\
\hline 8. & 08 & 6,75 ha & 4,58 ha & $67,85 \%$ & \\
\hline
\end{tabular}

Sumber: hasil analisis peneliti, 2019 
3. Lebar jalan masuk

Lebar jalan masuk adalah lebar jalan yang dapat dilalui kendaran/orang untuk masuk kedalam suatu permukiman. Untuk mengetahuinya harus dilakukan pengukuran secara langsung untuk mendapatkan hasilnya dan dapat langsung dimasukan kedalam klasifikasi sepeti tabel dibawah ini :

Tabel 14. Klasifikasi Lebar Jalan Masuk Berdasarkan Blok Permukiman (RW)

\begin{tabular}{|c|c|c|c|c|}
\hline No. & RW & Kode Jalan & $\begin{array}{l}\text { Rata-Rata Lebar Jalan } \\
\qquad(\mathrm{m})\end{array}$ & Skor Klasifikasi \\
\hline 1. & 01 & $60,61,62,63,64,65,66$ & $3,6 \mathrm{~m}$ & 1 (Buruk) \\
\hline 2. & 02 & $67,68,69,70,71$ & $2,71 \mathrm{~m}$ & 1 (Buruk) \\
\hline 3. & 03 & $\begin{array}{l}75,76,77,78,79,80,81,82,87, \\
88\end{array}$ & $2,47 \mathrm{~m}$ & 1 (Buruk) \\
\hline 4. & 04 & $\begin{array}{l}49,50,51,52,53,54,55,56,57 \\
58,59,72,73,83,84,85,86\end{array}$ & $4,44 \mathrm{~m}$ & 2 (Sedang) \\
\hline 5. & 05 & $\begin{array}{l}10,11,12,13,14,15,16,17,18 \\
19,20,21,23\end{array}$ & $3,44 \mathrm{~m}$ & 1 (Buruk) \\
\hline 6. & 06 & $\begin{array}{l}34,35,36,37,38,39,40,41,42 \\
43,44\end{array}$ & $2,5 \mathrm{~m}$ & 1 (Buruk) \\
\hline 7. & 07 & $\begin{array}{l}1,2,3,4,5,6,7,8,9,45,46,47 \\
48,74\end{array}$ & $4,13 \mathrm{~m}$ & 2 (Sedang) \\
\hline 8. & 08 & $\begin{array}{l}22,24,25,26,27,28,29,30,31, \\
32,33\end{array}$ & $3,42 \mathrm{~m}$ & 1 (Buruk) \\
\hline
\end{tabular}

Sumber: hasil analisis peneliti, 2019

\section{Lokasi permukiman}

Lokasi permukiman adalah posisi atau letak dari suatu permukiman. Hal ini berkaitan dengan posisi atau jarak suatu permukiman dari tempat-tempat penghasil polusi ataupun bencana misalnya terminal, pasar, stasiun, serta sungai dan gunung. Dan untuk membedakan antar permukiman yang lokasinya baik atau tidak, kita dapat lihat pada tabel klasifikasi berikut

Tabel 15. Klasifikasi Lokasi Permukiman di Kelurahan Sukun

\begin{tabular}{cccc}
\hline No. & RW & Keterangan Lokasi & Skor (Klasifikasi) \\
\hline 1. & 01 & Ada 2 sungai yang dekat dengan permukiman & 1 (Buruk) \\
\hline 2. & 02 & Ada 2 sungai yang dekat dengan permukiman & 1 (Buruk) \\
\hline 3. & 03 & Sebagian besar jauh dari sungai & 2 (Sedang) \\
\hline 4. & 04 & Dekat dengan sungai dan ada pasar & 1 (Buruk) \\
\hline 5. & 05 & Jauh dari sungai, pasar, dan lainnya & (Baik) \\
\hline 6. & 06 & Sebagian permukiman dilewati 2 sungai dan sebagian dekat & (Buruk) \\
\hline 7. & 07 & Sebagar & 2 (Sedang) \\
\hline 8. & 08 & Jauh dari sungai, pasar, dan lainnya & 3 (Baik)
\end{tabular}

5. Kondisi jalan masuk

Kondisi jalan masuk di semua blok yang terdapat diwilayah Kelurahan Sukun sudah disemenisasi ataupun diaspal sesuai dengan hasil observasi dari peneliti. Jadi sesuai dengan harkat yang telah ditetapkan seperti tabel di bawah ini: 
Tabel 16. Klasifikasi Kondisi Jalan Masuk di Kelurahan Sukun

\begin{tabular}{cclc}
\hline No & RW & \multicolumn{1}{c}{ Keterangan } & Skor (Klasifikasi) \\
\hline 1. & 01 & Sudah di aspal atau di semen & 3 (Baik) \\
\hline 2. & 02 & Sudah di aspal atau di semen & 3 (Baik) \\
\hline 3. & 03 & Sudah di aspal atau di semen & 3 (Baik) \\
\hline 4. & 04 & Sudah di aspal atau di semen & 3 (Baik) \\
\hline 5. & 05 & Sudah di aspal atau di semen & 3 (Baik) \\
\hline 6. & 06 & Sudah di aspal atau di semen & 3 (Baik) \\
\hline 7. & 07 & Sudah di aspal atau di semen & 3 (Baik) \\
\hline 8. & 08 & Sudah di aspal atau di semen & 3 (Baik)
\end{tabular}

Sumber: hasil analisis peneliti, 2019

\section{Pohon pelindung}

Pohon pelindung yang akan dibahas adalah pohon pelindung yang berada disisi jalan masuk. Hal ini bertujuan untuk menyaring udara dari polusi yang dihasilkan oleh kendaraan yang keluar dan masuk dari suatu permukiman. Dan klasifikasi dari pohon pelindung dapat dilihat pad tabel berikut :

Tabel 17. Klasifikasi Pohon Pelindung di Tiap Rw di Kelurahan Sukun

\begin{tabular}{cccc}
\hline No. & RW & Rata-rata Pohon Pelindung & Skor (Klasifikasi) \\
\hline 1. & 01 & Ada & 2 (Baik) \\
\hline 2. & 02 & Ada & 2 (Baik) \\
\hline 3. & 03 & Ada & 2 (Baik) \\
\hline 4. & 04 & Ada & 2 (Baik) \\
\hline 5. & 05 & Ada & 2 (Baik) \\
\hline 6. & 06 & Ada & 2 (Baik) \\
\hline 7. & 07 & Ada & 2 (Baik)
\end{tabular}

Sumber: hasil analisis peneliti, 2019

7. Ketersediaan air bersih

Ketersediaan air bersih yang dimaksud adalah pemenuhan kebutuhan masyarakat akan air bersih. Hal ini dilihat dapat dari banyak atau sedikitnya masyarakat yang sudah menggunakan PDAM atau masih menggunakan sumur bor atau yang lainnya, atau bahkan PDAM dan sumur bor. Untuk dapat mengetahui perbedaan suatu permukiman dangan yang permukiman lainnya dalam memenuhi kebutuhan akan air bersih, dapat dilihat dalam tabel berikut :

Tabel 18. Klasifikasi Ketersediaan Air Bersih di Kelurahan Sukun Berdasarkan 3 Sampel

\begin{tabular}{cccc}
\hline No. & RW (sampel) & Keterangan & Skor (Klasifikasi) \\
\hline 1. & 05 & $\begin{array}{c}\text { Sebagian besar }(>50 \%) \text { masyarakat sudah menggunakan } \\
\text { PDAM dan jarang menggunakan sumur }\end{array}$ & 3 (Baik) \\
\hline 2. &, 07 & Semua sudah menggunakan PDAM & 3 (Baik) \\
\hline 3. & 08 & Yang menggunakan PDAM sekitar 35\% dan yang masih \\
& & menggunakan sumur 65\% & (Sedang) \\
\hline
\end{tabular}

Sumber: hasil analisis peneliti, 2019

8. Polusi udara

Polusi udara adalah masalah yang perlu diperhatikan, karena udara yag tercmar dapat menyebabkan penyakit bagi yang menghirupnya. Polusi udara biasanya dihasilkan oleh kendaraan bermotor, pembakaran sampah, dan lainnya. Untuk Kelurahan Sukun, peneliti telah mengabil sampel yaitu dari $3 \mathrm{RW}$ yang sama seperti di poin ketersediaan air, yaitu RW 05 , RW 07, dan RW 08. Dan contoh pengklasifikasiannya dapat dilihat pada tabel berikut : 
Tabel 19. Klasifikasi Polusi Udara di Kelurahan Sukun

\begin{tabular}{cccc}
\hline No. & RW (sampel) & Keterangan & Skor (Klasifikasi) \\
\hline 1. & 05 & $\begin{array}{c}\text { Tidak Mengganggu (jauh dari jalan umum, } \\
\text { banyak jalan masuk ke permukiman dan } \\
\text { banyak pohon pelindung) }\end{array}$ & 3 (Baik) \\
\hline 2. & 07 & $\begin{array}{c}\text { Sedikit mengganggu (dekat jalan umum- } \\
\text { banyak kendaraan dan banyak pohon } \\
\text { pelindung) }\end{array}$ & 2 (Sedang) \\
\hline 3. & 08 & $\begin{array}{c}\text { Sedikit Mengganggu (jauh dari jalan umum, } \\
\text { banyak jalam masuk ke permukiman dan } \\
\text { banyak pohon pelindung. tapi bau sampah } \\
\text { dari TPA kadang mengganggu) }\end{array}$ & \\
\hline
\end{tabular}

Sumber: hasil analisis peneliti, 2019

9. Polusi suara

Polusi suara berkaitan erat dengan ketenangan. Polusi suara adalah keributan yang ditimbulkan oleh suara manusia, kendaraan, dan lainnya. Polusi suara biasanya terjadi di permukiman yang padat dan dekat dengan tempat umum seperti pasar, terminal, stasiun, dan jalan raya. Dan untuk Kelurahan Sukun, peneliti telah mengambil sampel di 3 RW, yaitu : RW 05, RW 07, dan RW 08. Dan cara menglasifikasikan polusi suara dapat dilihat pada tabel dibawah ini :

Tabel 20. Klasifikasi Polusi Suara di Kelurahan Sukun

\begin{tabular}{cccc}
\hline No. & RW (sampel) & Keterangan & Skor (Klasifikasi) \\
\hline 1. & 05 & $\begin{array}{c}\text { Sedikit mengganggu (suara kendaraan - } \\
\text { banyak jalan masuk ke permukiman) }\end{array}$ & 2 (Sedang) \\
\hline 2. & 07 & $\begin{array}{c}\text { Sangat mengganggu (suara kendaraan - dekat } \\
\text { jalan umum dan banyak jalan masuk ke } \\
\text { permukiman) }\end{array}$ & 1 (Buruk) \\
\hline 3. & 08 & $\begin{array}{c}\text { Sedikit mengganggu (suara kendaraan - } \\
\text { banyak jalan masuk ke permukiman) }\end{array}$ & 2 (Sedang) \\
\hline
\end{tabular}

Sumber: hasil analisis peneliti, 2019

Setelah semua parameter ditemukan hasilnya, sekarang yang akan dilakukan adalah mencari jumlah skor tertinggi dan terendah untuk dapat mencari intervalnya. Dan setelah ditemukan intervalnya maka kita dapat melajutkan dengan pembagian klasifikasi kualitas permukiman dari masing-masing blok permukiman atau RW di Kelurahan Sukun. Untuk menghitung jumlah skor menggunakan rumus sebagai berikut:

Harkat Total Citra $=(\mathrm{Ax} 3)+(\mathrm{Bx} 1)+(\mathrm{Cx} 2)+(\mathrm{Dx} 3)+(\mathrm{Ex} 2)+(\mathrm{Fx} 2)+(\mathrm{G})+(\mathrm{H})+(\mathrm{I})$

(Sumber : Ditjen Cipta Karya, Dep. PU (2006) dalam Mudzakir)

Keterangan:

A : Harkat kepadatan permukiman

B : Harkat tata letak permukiman

C : Harkat pohon pelindung jalan

D : Harkat lebar jalan masuk

E : Harkat kondisi jalan masuk

F : Harkat lokasi permukiman

G : Harkat ketersediaan air bersih

H : Harkat polusi udara

I : Harkat polusi suara 
Harkat Total Citra $($ nilai terendah $)=(1 \times 3)+(1 \times 1)+(1 \times 2)+(1 \times 3)+(1 \times 2)+(1 \times 2)+1+1+1$ $=16$

Harkat Total Citra (nilai tertinggi) $=(3 \times 3)+(3 \times 1)+(2 \times 2)+(3 \times 3)+(3 \times 2)+(3 \times 2)+3+3+3$ $=46$

Setelah menemukan nilai tertinggi dan terendah, selanjutnya dilakukan penentuan intervalnya dengan menggunakan rumus sebagai berikut:

$$
\text { Interval Kelas }=\frac{(\text { Skor tertinggi-skor terendah })}{\text { jumlah kelas yang diinginkan }}
$$

(Sumber : Ditjen Cipta Karya, Dep. PU (2006) dalam Mudzakir)

Jadi, hasilnya adalah:

Interval Kelas $=\frac{(46-16)}{3}$

Interval Kelas $=10$

Setelah mendapatkan intervalnya, maka dilanjutkan dengan memasukan kedalam tabel seperti tabel 10 dengan nilai terendah sebagai awalnya. Maka hasilnya sebagai berikut :

Tabel 21. Klasifikasi Kualitas Permukiman

\begin{tabular}{ccc}
\hline Total Harkat & Klasifikasi & Harkat(Score) \\
\hline $36-45$ & Baik & I \\
\hline $26-35$ & Sedang & II \\
\hline $16-25$ & Buruk & III
\end{tabular}

Sumber: hasil analisis peneliti, 2019

Dilihat dari tabel klasifikasi kualitas permukiman diatas, maka hasil untuk seluruh blok atau RW di Kelurahan Sukun adalah sebagai berikut:

Tabel 22. Harkat/Skor Total Tiap RW di Kelurahan Sukun

\begin{tabular}{cccccccccccc}
\hline No. & RW & $(\mathrm{Ax} 3)$ & $(\mathrm{B} \times 1)$ & $(\mathrm{C} \times 2)$ & $(\mathrm{Dx} 3)$ & $(\mathrm{Ex} 2)$ & $(\mathrm{Fx} 2)$ & $(\mathrm{G})$ & $(\mathrm{H})$ & $(\mathrm{I})$ & Jumlah total Harkat \\
\hline 1. & 01 & $(2 \times 3)$ & $(1 \times 1)$ & $(2 \times 2)$ & $(1 \times 3)$ & $(3 \times 2)$ & $(1 \times 2)$ & $(3)$ & $(2)$ & $(2)$ & 29 \\
\hline 2. & 02 & $(2 \times 3)$ & $(2 \times 1)$ & $(2 \times 2)$ & $(1 \times 3)$ & $(3 \times 2)$ & $(1 \times 2)$ & $(3)$ & $(2)$ & $(2)$ & 30 \\
\hline 3. & 03 & $(3 \times 3)$ & $(1 \times 1)$ & $(2 \times 2)$ & $(1 \times 3)$ & $(3 \times 2)$ & $(2 \times 2)$ & $(3)$ & $(2)$ & $(2)$ & 34 \\
\hline 4. & 04 & $(2 \times 3)$ & $(2 \times 1)$ & $(2 \times 2)$ & $(2 \times 3)$ & $(3 \times 2)$ & $(1 \times 2)$ & $(3)$ & $(2)$ & $(2)$ & 33 \\
\hline 5. & 05 & $(1 \times 3)$ & $(3 \times 1)$ & $(2 \times 2)$ & $(1 \times 3)$ & $(3 \times 2)$ & $(3 \times 2)$ & $(3)$ & $(3)$ & $(2)$ & 33 \\
\hline 6. & 06 & $(1 \times 3)$ & $(3 \times 1)$ & $(2 \times 2)$ & $(1 \times 3)$ & $(3 \times 2)$ & $(1 \times 2)$ & $(3)$ & $(2)$ & $(2)$ & 28 \\
\hline 7. & 07 & $(1 \times 3)$ & $(3 \times 1)$ & $(2 \times 2)$ & $(2 \times 3)$ & $(3 \times 2)$ & $(1 \times 2)$ & $(3)$ & $(2)$ & $(1)$ & 32 \\
\hline 8. & 08 & $(1 \times 3)$ & $(3 \times 1)$ & $(2 \times 2)$ & $(1 \times 3)$ & $(3 \times 2)$ & $(1 \times 2)$ & $(2)$ & $(2)$ & $(2)$ & 31 \\
\hline
\end{tabular}

Sumber: hasil analisis peneliti, 2019

Dari hasil tabel 22 diatas, dimasukan ke klasifikasi kualitas permukiman yang dapat dilihat dalam tabel klasifikasi berikut: 
Tabel 23. Klasifikasi Kualitas Permukiman di Kelurahan Sukun

\begin{tabular}{cccc}
\hline RW & Total Harkat & Klasifikasi & Harkat(Score) \\
\hline 01 & 29 & Sedang & II \\
\hline 02 & 30 & Sedang & II \\
\hline 03 & 34 & Sedang & II \\
\hline 04 & 33 & Sedang & II \\
\hline 05 & 33 & Sedang & II \\
\hline 06 & 28 & Sedang & II \\
\hline 07 & 32 & Sedang & II \\
\hline 08 & 31 & Sedang &
\end{tabular}

Sumber: hasil analisis peneliti, 2019

\section{Pembahasan}

Kelurahan Sukun merupakan bagian dari Kecamatan Sukun Kota Malang, dengan luas wilayah \pm 137 Hektar, Koordinat Bujur: 112.63'10.04”, Koordinat Lintang: -7.99'07.98”, Ketinggian Diatas Permukaan Laut: 100 Meter dan jumlah penduduk sebanyak 18.742 jiwa terdiri dari 9.037 laki-laki dan 9.705 perempuan dengan jumlah Kepala Keluarga 4.419. Adapun mata pencaharian dari penduduk sangat beragam antara lain PNS, TNI/Polri, Pedagang, Buruh Industri/Perusahaan, Pengrajin dan lain-lain.

Secara administrasi Kelurahan Sukun memiliki 9 RW dan 110 RT, serta memiliki lembaga yang bergerak dalam bidang ekonomi yaitu BKM Sukun Jaya serta LPMK yang merupakan lembaga yang mewadahi pemberdayaan masyarakat baik dibidang pembangunan, sosial maupun ekonomi. Sedangkan untuk batas wilayah adalah sebagai berikut: sebelah Utara berbatasan dengan Kelurahan Kasin Kecamatan Klojen; sebelah Timur berbatasan dengan Kelurahan Kasin Kecamatan Klojen; sebelah Selatan berbatasan dengan Kelurahan Bandungrejosari Kecamatan Sukun; sebelah Barat berbatasan dengan Kelurahan Tanjungrejo Kecamatan Sukun.

Pembahasan diatas merupakan sebagian dari monografi Kelurahan Sukun (lokasi penelitian) yang juga termasuk sebagian dari data sekunder dalam penelitian. Namun dalam data sekunder diatas belum memenuhi semua data yang dibutuhkan dalam penelitian seperti lebar jalan masuk, kondisi jalan masuk, keberadaan pohon pelindung, dan beberapa lainnya yang termasuk indikator dalam menentukan kualitas suaru permukiman. Indikator-indikator penentu kualitas permukiman termasuk dalam sarana dan prasarana serta bangunan-bangunan hunian yang terdapat dalam suatu permukiman. Hal ini sesuai dangan pendapat "(Sumaatmadja, 1988), Permukiman adalah bagian permukaan bumi yang dihuni manusia meliputi segala sarana dan prasarana yang menunjang kehidupannya yang menjadi satu kesatuan dengan tempat tinggal yang bersangkutan."

Dikarenakan informasi data untuk indikator penentu kualitas permukiman yang dibutuhkan peneliti hampir tidak ada dalam data skunder maka dilakukan penelitian survey yang sesuai dengan pendapat (Mubyanto, 1981) survey merupakan satu cara yang utama untuk mengumpulkan data primer bila data sekunder dianggap belum cukup lengkap untuk menjawab sesuatu pertanyaan. Kalau data sekunder sudah cukup lengkap dan hipotesis sudah dapat diuji dengan data sekunder, maka pengumpulan data primer secara langsung dengan metode survey tidak perlu lagi. Penelitian survei yang dilakukan yaitu mengukur lebar jalan masuk ditiap RW di Kelurahan Sukun sekaligus mendata kondisi jalan masuk dan melihat keberadaan pohon pelindung serta tata letak bangunan dan lokasi permukiman.

Setelah dilakukan pengumpulan data primer, dilanjutkan dengan interpretasi citra dalam Google Earth dengan dasar analisis yaitu dari sebagian data dari lapangan untuk menentukan lokasi suatu objek dilapangan dan bagaimana objek itu berpengaruh terhadap kualitas permukiman seperti jalan dan permukiman (bangunan), dan lainnya. Hal ini sesuai dengan 
pendapat "(Ambarasakti, 2013) Interpretasi citra merupakan kegiatan mengkaji foto udara atau citra yang bertujuan untuk menganalisis objek dan menentukan arti pentingya objek tersebut."

Dalam interpretasi citra yang dilakukan oleh peneliti khususnya menentukan ukuran dari objek (bangunan), peneliti tidak langsung ke lapangan untuk mengukurnya melainkan langsung dilakukan pengukuran dalam citra Google Earth. Hal ini sesuai pendapat ahli tentang penginderaan jauh yakni salah satunya menurut "(Lillesand dan Kiefer, 1979), penginderaan jauh merupakan suatu ilmu dan seni untuk memperoleh data dan informasi dari suatu objek di permukaan bumi dengan menggunakan alat yang tidak berhubungan langsung dengan objek yang dikaji."

Setelah dilakukan interpretasi citra dalam Google Earth, dilanjutkan dengan memasukan citra ke aplikasi argis 10.2 yang merupakan salah satu aplikasi dalam pembuatan peta. Aplikasi argis juga merupakan salah satu komponen dalam Sistem Informasi Geografis (SIG). SIG menurut "(Burrough, 1986 ) Kumpulan alat yang powerful untuk mengumpulkan, menyimpan, menampilkan dan mentranformasikan data spasial dari dunia nyata (real world)." Aplikasi arcgis 10.2 digunakan untuk mentransformasikan data spasial dari dunia nyata (Kelurahan Sukun), menyimpan datanya serta menampilkannya dalam bentuk peta.

Dalam pembuatan peta (pemetaan) di aplikasi argis 10.2, peneliti menggabungkan indikator-indikator penentu kualitas permukiman menjadi satu serta menggabungkan pula wilayah-wilayah RW (blok permukiman) yang ada di Kelurahan Sukun yang ditampilkan dalam sebuah peta kualitas permukiman dengan beberapa peta untuk beberapa indikator pendukung kualitas prmukiman. Pemetaan yang dilakukan oleh peneliti sesuai dengan pendapat "(Juhadi dan Liesnoor, 2001), pemetaan yaitu sebuah tahapan yang harus dilakukan dalam pembuatan peta. Langkah awal yang dilakukan dalam pembuatan data, dilanjutkan dengan pengolahan data, dan penyajian dalam bentuk peta."

Hasil dari penelitian yang dilakukan oleh peneliti adalah Kelurahan Sukun termasuk kedalam kualitas permukiman yang sedang. Hal ini karena setelah dilakukan perhitungan yang sesuai dengan rumus dari "(Ditjen Cipta Karya, Dep. PU (2006) dalam Mudzakir)" untuk menghitung hasil dari jumlah semua indikator penentu kualitas permukiman, setiap RW di Kelurahan Sukun tidak mampu memenuhi nilai untuk klasifikasi kualitas permukiman baik.

Setelah mendapatkan hasil kualitas permukiman, peneliti menyimpulkan bahwa kualitas suatu permukiman akan menjadi buruk karena pembangunan yang sembarangan. Pembangunan yang sembarangan akan menyebab beberapa indikator penentu kualitas permukiman menjadi buruk seperti lebar jalan masuk karena pembangunan yang terlalu rapat dan indikator lokasi permukiman dikarenakan pembangunan yang terlalu dekat dengan sumber polusi (pasar) dan sumber bahaya (sungai). Pendapat peneliti sesuai dengan peneliti sebelumnya dalam jurnalnya bahwa, "kurangya kesadaran dari masyarakat setempat dengan membangun rumah liar disekitaran jalan raya, (Farizki dan Anurogo, 2017)."

Peta hasil penelitian tentang kualitas permukiman di Kelurahan Sukun, Kecamatan Sukun, Kota Malang: 


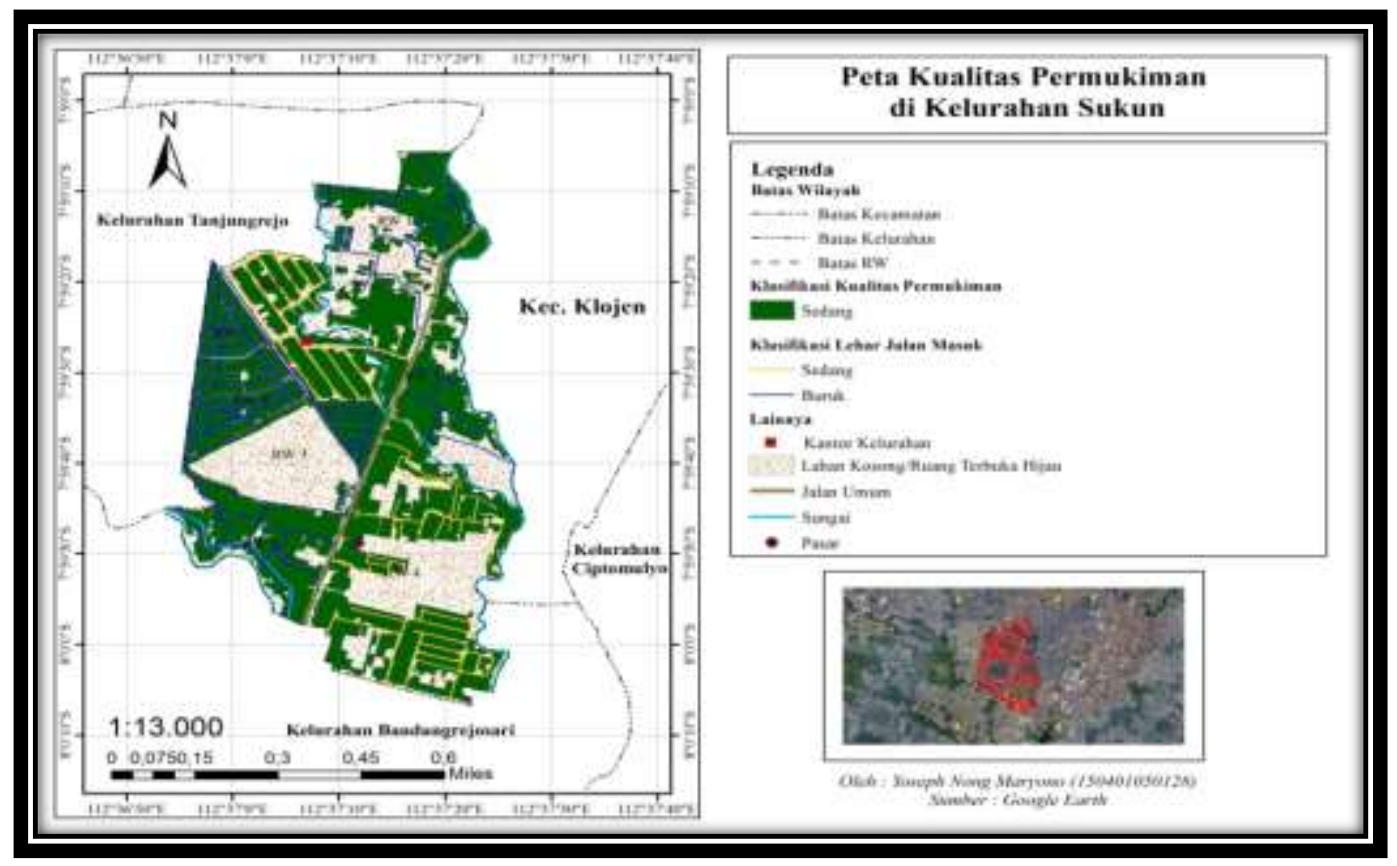

Gambar 1 Peta Kualitas Permukiman di Kelurahan Sukun

Diolah oleh : Yoseph Nong Maryono

Sumber : Google Earth Tahun 2019

\section{Kesimpulan}

Kualitas permukiman di Kelurahan Sukun (terbagi dalam 8 RW) termasuk dalam kualitas permukiman sedang. Hal ini dikarenakan rata-rata indikator penentu kualitas permukiman hanya mampu memenuhi nilai sedang, yang didapat dari pengukuran di lapangan dan interpretasi citra.

Adapun beberapa saran yang diharapkan dapan dilaksanakan sebagai berikut:

a) Pemerintah

Saran untuk pemerintah terlebih khusus pemerintahan Kelurahan Sukun adalah harus lebih memperhatikan pembangunan dalam permukiman dan juga tidak terlepas memperhatikan lingkungan agar kualitas permukiman di Kelurahan Sukun bisa mencapai kualitas baik.

\section{b) Masyarakat}

Saran untuk masyarakat khususnya masyarakat di Kelurahan Sukun, yaitu harus lebih memperhatikan lagi pembangunan terlebih khusus pembangunan tempat tinggal. Karena jika pembangunan tempat tinggal yang sembarangan akan dapat menurunkan kualitas dari suatu permukiman.

\section{c) Peneliti Selanjutnya}

Peneliti saat ini mengharapkan dan menyarankan bahwa untuk peneliti selanjutnya dapat menggunakan hasil peneliti saat ini sebagai acuan dalam penelitian lanjutan yang dilakukan oleh peneliti selanjutnya dan dapat dengan lebih baik lagi dalam membahas tentang kualitas permukiman. 


\section{Ucapan Terimakasih}

Dalam menyelesaikan penyusunan artikel/jurnal ini, tidak lepas dari bantuan berbagai pihak baik berupa sumbangan pikiran maupun sumbangan finansial sehingga pada kesempatan ini penulis ingin mengucapkan terimakasih kepada Universiats Kanjuruhan Malang, Minto Nugroho selaku Lurah Kelurahan Sukun, Keluarga dan teman-teman seperjuangan, yang telah menyumbangan gagasan berharga dalam menyelesaikan penulisan artikel/jurnal ini dan semua pihak yang tak mungkin disebutkan satu-persatu dalam artikel/jurnal ini.

\section{Daftar Rujukan}

Akbar dan Alfian, 2018. Kampung Tematik Sebagai Bentuk Partisipasi Masyarakat dalam Permasalahan Permukiman Kumuh di Kota Malang. Jurnal, Malang.

Ambarasakti, 2013. Pemetaan Kualitas Permukiman dengan Menggunakan Penginderaan Jauh dan SIG di Kecamatan Batam Kota, Batam. Jurnal, Batam.

Burrough, 1986. Sistem Informasi Geografis. Digibooks, Yogyakarta.

Ditjen Cipta Karya, 2006. Kajian Kualitas Permukiman Dengan Citra Quickbird Dan Sig Di Kecamatan Serengan Kota Surakarta. Jurnal, surakarta.

Farizki dan Anurogo, 2017. Pemetaan Kualitas Permukiman dengan Menggunakan Penginderaan Jauh dan SIG di Kecamatan Batam Kota, Batam. Jurnal, Batam.

Koestoer, 2001:46. Hubungan Kepadatan Permukiman Dengan Ketersediaan Infrastruktur. Universitas Diponegoro, Semarang.

Mubyanto, (1981). Dampak Promosi Melalui Vlog Terhadap Minat Beli Mahasiswa Universitas Atma Jaya Yogyakarta. Jurnal, Yogyakarta.

Prasetyo et.al, 2013. Pemetaan Kualitas Permukiman dengan Menggunakan Penginderaan Jauh dan SIG di Kecamatan Batam Kota, Batam. Jurnal, Batam.

Sugiyono, (2012:68). Metode Penelitian Kuantitatif Kualitatif dan R\&D. Bandung. Alfabeta

Sumaatmadja, 1988. Evaluasi Prasarana Dasar Permukiman Di Kelurahan Kima Atas Dan Kelurahan Kairagi Ii Di Kecamatan Mapanget. Jurnal, Manado.

Juhadi dan Liesnoor, 2001. Definisi Pemetaan. Tinjauan Pustaka (online), (http://eprints.ung. ac.id/5124/5/2012-1-57201-531408018-bab2-14082012065336.pdf), diakses 10 Januari $\underline{2019}$

Lillesand dan Kiefer (1979), Pengantar Pengideraan Jauh. Dari Academia, (Online), (https://www.academia.edu/8964229/BUKU_AJAR_PENGINDERAAN_JAU H), diakses 10 Januari 2019

UU No.1 tahun 2011 tentang Perumahan dan Kawasan Permukiman, BPHN. (online), (https://www.bphn.go.id/data/documents/11uu001.pdf), diakses januari 2019 